\title{
STATUS OF METABOLIC PROCESSES IN HORSES DURING SPRING PERIOD
}

Kravchenko N. 0.

Kharkiv State Zooveterinary Academy, Kharkiv, Ukraine

Kovalenko L. V., Rudenko O. P., Boiko V. S.

National Scientific Center "Institute of Experimental and Clinical Veterinary Medicine", Kharkiv, Ukraine

The purpose of these studies was to determine status of metabolic processes in clinically healthy horses of sport breeds in spring period. Blood samples for biochemical studies were collected from 12 clinically healthy 7-9 month-old stallions of Ukrainian horse breed at Dnipropetrovsk region equestrian club. Protein (albumin, globulin, urea and creatinine) and mineral (common calcium and inorganic phosphorus) metabolic statuses, level of glucose, vitamins $A$ and $E$ and acid, as well as activity of hepatospecific enzymes (ALT, AST and AP) were determined using common techniques. It has been found that common protein level was within the limits of physiologic norm, although the level of albumins was decreased at the average rate of $12.0 \%$, and the level of $\beta$ and $y$-globulins was increased at the average rates of 5.2 and $11.3 \%$ respectively. AST activity was decreased at the rate of $38.0 \%$ regarding to physiological norm. Thereby, urea and creatinine concentrations were within the referent levels. Hyperglycaemia was observed in $50.0 \%$ of tested animals with maximal excess at the rate of 44.0\%. Also, decreasing of common calcium and inorganic phosphorus levels was determined at the rate of 16.0 and $58.6 \%$, vitamins $A$ and $E$ - at the rate of 64.0 and $48,6 \%$ respectively, in comparison to lower level of physiological norm. The average index of acid capacity reached maximal referent levels. At the same time, it was increased in $33.3 \%$ of animals. Therefore, detected changes in biochemical indices in horse blood evidence that various metabolic disorders progress in clinically healthy stallions at spring and may furtherly lead to the appearance of metabolic syndrome

Keywords: horses, blood serum, metabolic syndrome, protein metabolism, macronutrients, vitamins

УДК 619:616.995.132:577.1:591.11.05:636.92

DOI 10.36016/VM-2019-105-18

\section{РІВЕНЬ БІЛКІВ I ІМУНОГЛОБУЛІНІВ У КРОВІ КРОЛІВ ЗА ПАСАЛУРОЗНОї ІНВАЗІЇ}

\author{
Дуда Ю. В. \\ Дніпровський державний аграрно-економічний університет, \\ Дніпро, Україна, e-mail: dudajulia1976@gmail.com
}

Прус М. П.

Національний університет біоресурсів і природокористування України, Київ, Україна

За впливу збудника Passalurus ambiguus у крові кролів, у порівнянні з аналогічними показниками здорових тварин, виявили достовірно високий $(p<0,001)$ вміст загального протеїну, глобулінів, ү-глобулінів, IgA, IgG, IgM і креатиніну та низькі рівні сечової кислоти та протеїнового коефріцієнту. Істотні зміни цих показників вказують на посилення імунного захисту

Ключові слова: пасалуроз, протеїновий обмін, Passalurus ambiguus, альбуміни, глобуліни

Вагомим напрямом розвитку м'ясного тваринництва у ряді країн $є$ кролівництво. Потенціал даної галузі полягає у скоростиглості, відносно низькій собівартості утримання, а також можливості розведення кролів в умовах великих механізованих товарних фрерм і особистих підсобних господарств [1]. Одним з факторів, що стримує розвиток галузі, є хвороби заразної етіології, серед яких гельмінтози посідають одне з головних місць. 3 багатьох гельмінтозів кролів на земній кулі кількісно домінуючим є пасалуроз [2-4]. На фрермах, де не дотримуються санітарногігієнічних вимог, зазвичай 40-90 \% кролів уражені пасалурозом [5, 6], при цьому інтенсивність інвазії складає від декількох гельмінтів до понад 100 тисяч гостриків [5].

Проблема пасалурозної інвазії в сучасному кролівництві України залишається досить актуальною, тому що вона характеризується високою контагіозністю та можливістю необмеженого поширення [7]. Отже, постійно ведуться дослідження з вивчення впливу збудника на організм кролів [8] і розробки ефективних лікувально-профрілактичних схем. 
Метою досліджень було визначити вплив збудника пасалурозу на рівень білків та імуноглобулінів у крові кролів.

Матеріали та методи. Робота виконувалась впродовж 2015-2018 рр. Експериментальна частина роботи виконана в ТОВ «Олбест» Дніпропетровської області та ТОВ «Кроликофрф Плюс» Черкаської області, в яких використовують кліткове утримання тварин з додержанням усіх зоогігієнічних вимог зі збалансованим раціоном годівлі. Лабораторні дослідження проводили в лабораторіях кафедри паразитології та ветсанекспертизи ДДАЕУ.

Для дослідів були відібрані аналогові групи кролів-самців 3-5-місячного віку каліфорнійської породи. За гельмінтоовоскопічними дослідженнями тварин було поділено на дві групи: контрольні - здорові тварини, та дослідні - хворі тварини. 3 метою визначення рівня ураженості кролів, їх екскременти досліджували за методом МакМастера [9].

Біохімічні дослідження сироватки крові проводили з використанням наборів реактивів фірми «Філісіт-Діагностика» (Україна, м. Дніпро). Спектрофотометричним методом у сироватці крові тварин визначали: вміст загального протеїну (НР010.01) - біуретовим методом, альбумінів (НР002.01) - 3 індикатором бромкрезоловим зеленим, глобулінів (розрахунковий показник) дорівнює різниці загального протеїну та альбумінів, глобулінові фракції (НР006.01) - методом осадження, протеїновий коефіцієнт (розрахунковий показник) обчислювали як співвідношення альбумінів до глобулінів, сечовину (НР018.01) - діацетилмонооксимним методом, сечову кислоту (НР017.01) - фоссфорновольфрамовим методом, креатинін (НР014.01) - методом Яфрфе-Поппера [10]. Рівень імуноглобулінів A $(\lg A), \quad G(\lg G), M(\lg M)$ визначали методом дискретного осадження за М. Костиною (1983) [11].

При роботі з тваринами дотримувалися вимог «Європейської конвенції щодо захисту хребетних тварин, які використовуються в експерименті та інших наукових цілях» (Страсбург, 18.03 .1986 р.). Статистичну обробку експериментальних результатів для визначення біометричних показників (середні значення та їх похибки, порівняння середніх значень за критерієм Стьюдента) здійснювали з використанням програми Microsoft Excel 16.

Результати роботи. Встановлено, що кролі, хворі на пасалуроз, мали різний рівень інтенсивності інвазії (II). Це в подальшому дало змогу за рівнем II розділити дослідних тварин на три групи: низький $(I I=276,47 \pm 43,33$ яєць/г фрекалій $)-$ I дослідна, високий $(I I=2446,67 \pm$ 422,11 яєць/г фекалій) - II дослідна та середній рівень II (II = 1293,75 \pm 275,80 яєць/г фрекалій) III дослідна група. У фекаліях тварин контрольної групи яєць гельмінтів не знаходили.

Вміст загального протеїну крові та його окремих фрракцій може змінюватися з різних причин, а саме: за наявності патологічного процесу та його динаміки, ступенем захворювання. Тому визначення вмісту як загального протеїну, так і окремих його фрракцій має велике клінікодіагностичне значення (табл.).

Таблиця - Характеристика білкового обміну кролів за пасалурозної інвазії (M $\pm \mathrm{m})$

\begin{tabular}{|c|c|c|c|c|c|}
\hline \multirow{2}{*}{\multicolumn{2}{|c|}{ Показники }} & \multirow{2}{*}{$\begin{array}{c}\text { 3дорові } \\
\text { тварини } \\
(\mathrm{n}=30)\end{array}$} & \multicolumn{3}{|c|}{ Хворі тварини, групи } \\
\hline & & & $\begin{array}{c}\mathrm{I} \\
(\mathrm{n}=17)\end{array}$ & $\begin{array}{c}\text { II } \\
(n=15)\end{array}$ & $\begin{array}{c}\text { III } \\
(n=32)\end{array}$ \\
\hline \multicolumn{2}{|l|}{ Загальний протеїн, г/л } & $46,34 \pm 1,08$ & $63,94 \pm 3,68^{\star \star *}$ & $76,86 \pm 4,18^{* * *}$ & $69,99 \pm 2,96^{* * *}$ \\
\hline \multicolumn{2}{|l|}{ Альбуміни, \% } & $63,43 \pm 1,70$ & $47,41 \pm 3,90^{\star \star *}$ & $36,38 \pm 3,37^{* * *}$ & $42,24 \pm 2,75^{\star \star *}$ \\
\hline \multicolumn{2}{|l|}{ Глобуліни, \% } & $36,57 \pm 1,70$ & $52,59 \pm 3,90^{* * *}$ & $63,62 \pm 3,37^{* * *}$ & $57,76 \pm 2,75^{\star * *}$ \\
\hline \multirow{4}{*}{ Глобулінові фракції, \% } & $\alpha_{1}$ & $4,20 \pm 0,50$ & $4,61 \pm 0,62$ & $5,98 \pm 0,66$ & $5,30 \pm 0,46$ \\
\hline & $\alpha_{2}$ & $6,61 \pm 0,78$ & $8,90 \pm 1,75$ & $13,66 \pm 2,08^{* *}$ & $10,60 \pm 1,37^{*}$ \\
\hline & $\beta$ & $7,94 \pm 0,76$ & $9,29 \pm 1,75$ & $14,64 \pm 2,80^{* *}$ & $13,09 \pm 1,74^{*}$ \\
\hline & $y$ & $17,82 \pm 1,23$ & $25,36 \pm 2,16^{\star *}$ & $25,34 \pm 3,24^{\star *}$ & $24,38 \pm 1,88^{* *}$ \\
\hline \multicolumn{2}{|l|}{ Протеїновий коефріцієнт } & $1,71 \pm 0,17$ & $0,79 \pm 0,16^{* \star *}$ & $0,52 \pm 0,12^{\star \star *}$ & $0,64 \pm 0,11^{* \star *}$ \\
\hline \multicolumn{2}{|l|}{ Сечовина, ммоль/л } & $8,57 \pm 0,97$ & $7,03 \pm 0,54$ & $7,39 \pm 0,40$ & $7,20 \pm 0,34$ \\
\hline \multicolumn{2}{|c|}{ Сечова кислота, мкмоль/л } & $111,40 \pm 7,35$ & $18,00 \pm 1,31^{\text {***}}$ & $23,36 \pm 3,65^{* * *}$ & $20,51 \pm 1,88^{* * *}$ \\
\hline \multicolumn{2}{|l|}{ Креатинін, мкмоль/л } & $39,73 \pm 1,32$ & $56,67 \pm 2,95^{\star \star \star}$ & $58,20 \pm 2,96^{\star * *}$ & $57,38 \pm 2,06^{\star \star *}$ \\
\hline
\end{tabular}

Примітки: ${ }^{*}-p<0,05,{ }^{* *}-p<0,01,{ }^{* * *}-p<0,001$ порівняно із здоровими тваринами.

У крові хворих тварин усіх рівнів II вміст загального протеїну був достовірно $(p<0,001)$ високим. Даний показник був вищий в 1,38 разу (з низькою II), в 1,66 разу (з високою II), в 1,51 разу 
(з середньою II) порівняно зі здоровими кролями, за рахунок підвищеного вмісту глобулінів відповідно в 1,44 разу $(p<0,001), 1,74$ разу $(p<0,001), 1,58$ разу $(p<0,001)$. Такий перерозподіл протеїнів призвів до вірогідного $(p<0,001)$ зниження протеїнового коефіцієнту у 2,16, 3,29 та 2,67 разу відповідно у крові тварин I, II, III груп - за рахунок вірогідно низького відсотка вмісту альбумінів. Найбільш істотні зміни вище вказаних показників спостерігали у крові кролів з високим рівнем II.

Визначення вмісту глобулінових фракцій у крові має велике діагностичне, прогностичне та терапевтичне значення за гельмінтозних хвороб. У хворих на пасалуроз кролів з усіма рівнями II реєстрували достовірно підвищений вміст ү-глобулінів, до фракції якої входить основна частина імуноглобулінів, від 6,58 до 7,54 \% ( $<0,01)$ порівняно з аналогічними показниками здорових тварин. За впливу збудника Passalurus ambiguus у крові кролів спостерігали високий вміст $\beta$-глобулінів, які містять компоненти комплементу та частину імуноглобулінів: у II та III дослідних групах на $6,70 \%(p<0,01)$ та $5,15 \%(p<0,05)$ проти контрольних. У крові тварин цих же груп відмітили збільшений вміст $\alpha_{2}$-глобулінів на 7,05\% $(p<0,01)$ та 3,99\% $(p<0,05)$ у порівнянні 3 контролем. Підвищений вміст $\gamma$ - та $\beta$-глобулінових фрракцій за впливу збудника вказує на посилення імунного захисту. Суттєвих змін у концентрації $\alpha_{1}$-глобулінів не виявили.

Показники вмісту сечовини у крові кролів, хворих на пасалуроз, не змінились порівняно зі здоровими. Істотно низький рівень сечової кислоти (а саме - у 4,77 ( $p<0,001), 6,19$ ( $<<0,001)$ та 5,43 ( $p<0,001)$ разу відмітили у крові кролів, захворювання яких спричинено збудником Passalurus ambiguus, що може бути обумовлено порушенням процесу утворення ії̈ в печінці на фоні підвищення виведення кислоти через кишечник і нирки.

Рівень креатиніну в сироватці крові дослідних кролів був достовірно високим: відповідно на 42,64 ( $p<0,001), 46,49$ ( $p<0,001)$ та 44,42 \% ( $<<0,001)$ порівняно 3 контролем.

Гуморальними факторами специфічного імунного захисту слизових оболонок $\epsilon$ антитіла. Секреторні IgA та IgG, що продукуються локально, становлять більшість всіх антитіл, які утворюються в організмі протягом доби [11]. Паразитування збудника Passalurus ambiguus призводить до порушення синтезу імуноглобулінів (рис.).

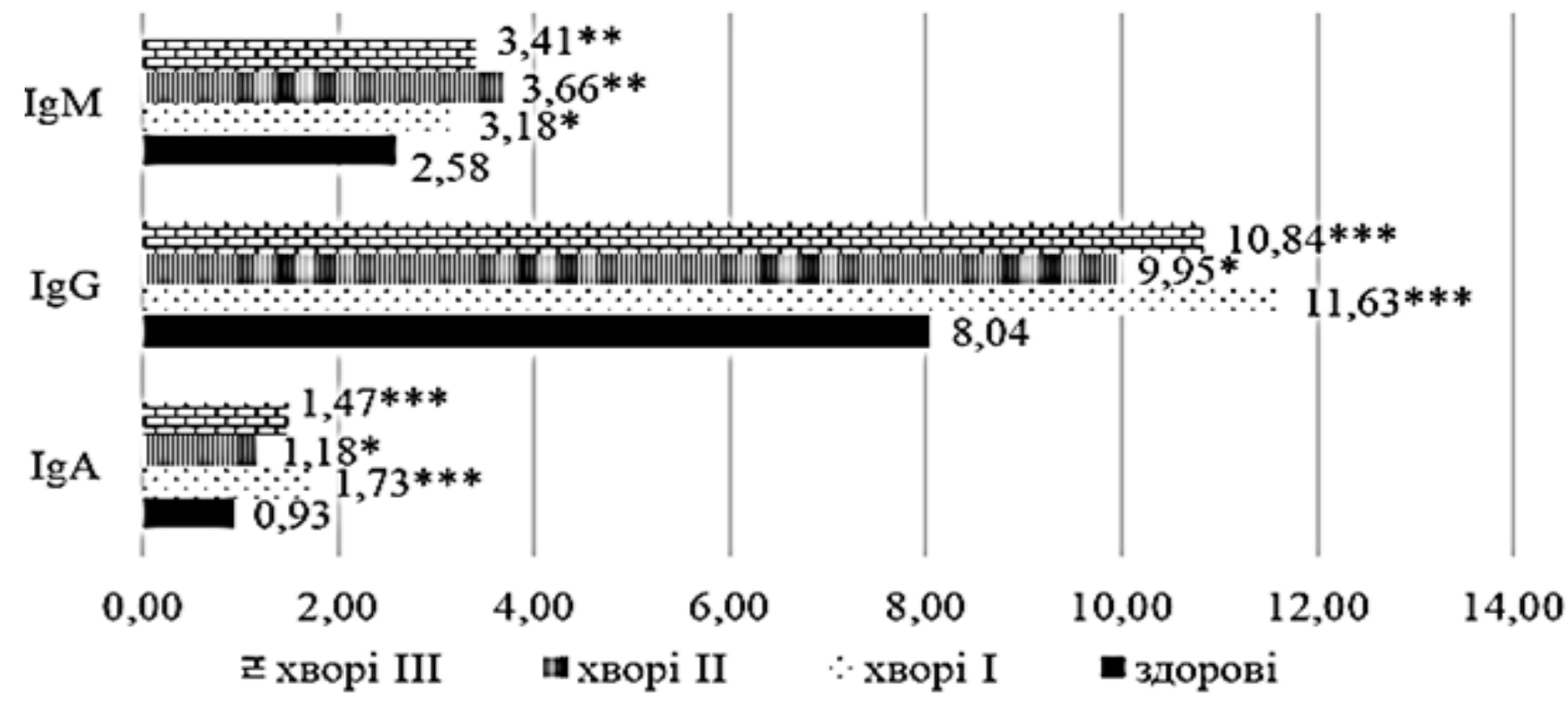

Рис. Вміст $\lg A, \lg G, \lg М$ у крові кролів за пасалурозної інвазії, г/л ( ${ }^{*}-p<0,05,{ }^{* *}-p<0,01$, *** $-p<0,001$ порівняно із здоровими тваринами).

З даних, наведених на рисунку, видно, що у крові кролів I, II та III дослідних груп вміст IgA був вищим відповідно у 2,22 ( $<<0,001), 1,51(\mathrm{p}<0,001)$ та $1,88(\mathrm{p}<0,001)$ разу порівняно 3 контрольними тваринами. Схожі зміни спостерігались також із вмістом IgG та IgM.

У крові всіх хворих кролів рівень IgG був високим $(p<0,001)$ : у 2,16 разу (у тварин з низькою II) до 1,85 разу (у тварин з високою II) порівняно зі здоровими. У крові хворих кролів спостерігався вірогідно ( $<<0,001)$ високий рівень IgМ проти контролю в 1,58, 1,82 та 1,70 разу відповідно у I, II, III груп. Відомо, що гуморальні антитіла, які відносяться до класів $\lg \mathrm{G}$ та $\lg$, здатні пошкоджувати 
тіло гельмінтів, фрормувати преципітати навколо їх вивідних отворів, що порушують нормальний перебіг фрізіологічних процесів паразита та зв'язувати їх ферменти [12].

Висновки. У крові кролів за впливу збудника Passalurus ambiguus достовірно високими були вміст загального протеїну, глобулінів, ү-глобулінів, $\operatorname{lgA}, \lg G, \lg M$ і креатиніну порівняно зі здоровими. Найбільш істотні зміни показників спостерігали у крові кролів з високим рівнем інтенсивності інвазії. Тільки у крові тварин II та III дослідних груп були достовірно вищими вміст $\beta$-глобулінів і $\alpha_{2}$-глобулінів. Вище описані зміни за впливу збудника вказують на посилення імунного захисту. Істотно знижений рівень сечової кислоти та протеїнового коефріцієнту за рахунок низького відсотка альбумінів виявили у крові хворих кролів, що може бути обумовлено порушенням процесу синтезу їх у печінці на фоні підвищеного виведення.

Перспективи подальших досліджень. Вивчити вплив збудника Passalurus ambiguus на показники неспецифічного імунітету кролів.

\title{
Список літератури
}

1. Паладян 3. Економічна ефективність організації невеликих приватних формувань по виробництву продукції кролівництва. Тваринництво України. 2004. № 9. С. 12-14.

2. Mykhailiutenko S. M. [et al.]. Pathomorphological changes in the large intestine of rabbits parasitised by Passalurus ambiguus (Nematoda, Oxyuridae). Regul. Mech. Biosyst. 2019. Vol. 10, No. 1. P. 69-74.

3. Дуда Ю. В., Шевчик Р. С., Кунєва Л. В. Вплив Passalurus ambiguus та Cysticercus pisiformis на вихід продуктів забою кролів. Аграрний вісник Причорномор'я. Ветеринарні науки. 2019. Вип. 93. С. 234-239.

4. Sonon T. Enquete sur Pelevage du lapin dans la province du Mono. Memoire pour obtention du DETS, Abomeycalavi (Benin). 1986. P. 123-128.

5. Дубницкий А. А. Пассалуроз. Болезни кроликов. Москва : Колос, 1974. С. 184-190.

6. Флориан Дага Даджо. Пассалуроз кроликов в условиях Московской области (биология возбудителя, эпизоотология и меры борьбы) : автореф. дис ... канд. вет. наук. Москва, 1997. 22 с.

7. Дуда Ю. В., Кунєва Л. В., Христян О. П. Показники білкового обміну кролів за пасалурозної інвазії. Науковотехнічний бюлетень НДЦ біобезпеки та екологічного контролю ресурсів АПК. 2017. Т. 5, № 1. С. 93-96.

8. Дуда Ю. В., Прус М. П. Показники клітинного імунітету крові кролів за впливу збудника пасалурозу. Ветеринарна біотехнологія : бюл. 2019. Вип. 35. С. 35-44.

9. Пономар С. І., Гончаренко В. П., Соловйова Л. М. Довідник з диференціювання збудників інвазійних хвороб тварин. Київ : Аграрна освіта, 2010. С. 34-37.

10. Влізло В. В. [та ін.]. Лабораторні методи досліджень у біології, тваринництві та ветеринарній медицині. Львів : Сполом, 2012. 764 с.

11. Маслянко Р. П. [та ін.]. Методичні рекомендації для оцінки та контролю імунної системи тварин. Львів, 2001. $87 \mathrm{c}$.

12. Гришина Е. А. Иммуно-биологичные основы патогенеза кишечных нематодозов : дис. ... канд. биол. наук. Москва, 2019. 278 с.

\section{LEVELS OF PROTEINS AND IMMUNOGLOBULINS IN RABBIT BLOOD DURING PASSALUROSIS}

\author{
Duda Yu. $V$. \\ Dnipro State Agrarian and Economic University, Dnipro, Ukraine
}

Prus M. $P$.

National University of Life and Environmental Sciences of Ukraine, Kiev, Ukraine

The purpose of our work was to determine the influence of Passalurus ambiguus on proteinogram and the level of immunoglobulins in the blood of rabbits. Analog groups of male rabbits of 3-5 months of age were selected for the experiments. Intensity of invasion was determined by the method of the MacMaster. By spectrophotometric method in the blood of animals there was determined: the content of total protein, albumin, globulin fractions, the level of IgA, IgG, IgM - discrete deposition method according to M. Kostina. Rabbits with pasalurosis have different levels of invasion intensity (II): low (II = 276.47 \pm 43.33 eggs $/ g$ of feces), high (II = 2,446.67 \pm 422.11 eggs/g of feces) - II and medium (II = 1,293.75 \pm 275.80 eggs/g of feces) - III research groups. We did not find eggs in the control group. The total protein content was significantly $(p<0.001)$ higher - from 1.38 times to 1.66 times compared with healthy ones, due to an increase in the content of globulins from 2.08 times $(p<0.001)$ to 2.26 times $(p<0.001)$, which led to a decrease in the protein ratio from 2.16 times $(p<0.001)$ to 3.29 times $(p<0.001)$ in sick animals with different II. We recorded a high content of $\gamma$-globulins almost 1.4 times in these animals compared to healthy ones. We observed a high content of $\beta$-globulins and $\alpha_{2}$-globulins by $6.70 \%$ and $7.05 \%(p<0.01)$ and $5.15 \%$ and $3.99 \%(p<0.05)$ in animals II and III experimental groups in comparison with control group. A decreased level of uric acid from 4.77 times $(p<0.001)$ to 6.19 times $(p<0.001)$ in rabbits with passalurosis is probably due to a violation of the process of its formation in the liver against the background of an increase in acid output through the intestines and kidneys. The creatinine level in experimental rabbits was significantly higher in groups I, II, III by 42.64\% ( $p<0.001), 46.49 \%(p<0.001)$ and $44.42 \%(p<0.001)$, 
respectively, compared with the control. IgA and IgG levels were high $(p<0.001)$ in comparison to healthy rabbits: 2.22 and 2.16 times (in animals with low II), 1.51 and 1.85 times (in animals with high II). We observed a significant $(p<0.001)$ high level of IgM against the control 1.58 times, 1.82 times and 1.70 times, respectively, in groups I, II, III of infected rabbits. The content of total protein, globulins, $y$-globulins, IgA, IgG, IgM and creatinine were significantly higher $(p<0.001)$ in the blood of sick rabbits than healthy ones. We observed significant changes in the proteinogram of rabbits with high levels of II. These changes indicate an increase in the body's immune defense under the influence of Passalurus ambiguus. We found a decreased level of uric acid and a protein coefficient due to the low percentage of albumin in sick rabbits. This is possibly due to a violation of the process of their formation in the liver against the background of increased output

Keywords: passalurosis, protein metabolism, Passalurus ambiguus, albumins, globulins

УДК 619:616-008/009:612.017.1:636.4.082.35

DOI 10.36016/VM-2019-105-19

\title{
СТРЕСОВИЙ СТАН ТА ІМУНОЛОГІЧНИЙ СТАТУС МОЛОДНЯКУ СВИНЕЙ
}

\author{
Чорний М. В. \\ Харківська державна зооветеринарна академія, Харків, Україна, e-mail: nycvas@ukr.net
}

У статті наведено результати досліджень щодо впливу перегрупувань поросят у різному віці на резистентність їх організму, імунологічний статус, продуктивні якості та збереженість молодняку свиней. Дослідження показали, що перегрупування та переміщення поросят підсисного періоду викликають занепокоєння, зниження продуктивних якостей та прояви діареї

Ключові слова: безпека, діарея, жива вага, імунний статус, стрес, поросята

В умовах промислового ведення свинарства, якому притаманне безвигульне утримання, дефіцит природної інсоляції, малозмінюваний мікроклімат $[5,9,10]$ обумовлюють стресову дію [2, 11], знижують резистентність організму свиней, особливо молодняку поросят [3, 8], що призводить до шлунково-кишкових захворювань [6, 7]. Пусковим механізмом виникнення незаразних хвороб $€$ несприятливі фрактори (перегрупування, раннє відлучення, несприятливі мікрокліматичні умови, неповноцінна годівля), які спричинюють навантаження на організм $[1,4]$.

Що стосується досліджень з вивчення «факторних» інфекцій, обумовлених дією технології виробництва, то їх виконано недостатньо. Тому з'ясування впливу абіотичних стресових фракторів на імунний статус свиней $€$ актуальним 3 метою їх зниження без масового використання лікарських засобів.

Мета роботи - з'ясувати вплив перегрупувань у різному віці на резистентність організму, імунологічний статус, продуктивні якості та збереженість молодняку свиней.

Матеріали та методи. Робота проводилась у ТОВ «Стас» на поросятах великої білої породи та їх помісях з ландрас. У досліді використано 60 тварин від народження до двомісячного віку по 20 голів у кожній дослідній групі.

Контрольна група утримувалась від народження до 60-добового віку гніздами, а потім свиней переводили в цех дорощування, дослідна-1 - до 10-добового віку утримували гніздами, а потім проводили одноразове перегрупування за живою масою. Поросят з дослідної-2 перегруповували за живою масою у 5-, 10-, 21- та 30-добовому віці та утримували по 10 голів у станку. Гігієнічні умови та рівень годівлі для дослідних груп були однаковими.

Використовували наступні методи дослідження: загальноприйняті в зооветеринарії (жива вага, середньодобовий приріст, захворюваність, збереженість), гігієнічні (умови мікроклімату, санітарний режим), гематологічні (морфологічний склад крові), імунологічні (клітинні та гуморальні показники резистентності), біохімічні (білковий склад сироватки крові), етологічні та математичні. Вміст гемоглобіну визначали гемометром Салі, кількість еритроцитів і лейкоцитів у камері Горяєва за А. А. Кудрявцевою та ін. У сироватці крові загальний білок визначали рефррактометром на приладі IРФ - 22, загальний кальцій - комплекснометрично, неорганічний фоссфор - колориметрично з реактивом 167 МВА. Гуморальні показники неспецифічної природної резистентності визначали: БАСК - нефелометрично за Смірновою О. В. та ін., 1966; 